\title{
Photonic crystal fiber based evanescent-wave sensor for detection of biomolecules in aqueous solutions
}

Jensen, Jesper Bevensee; Pedersen, L H; Carlsen, A; Hoiby, P E; Nielsen, L B; Bjarklev, Anders Overgaard; Hansen, T B

Published in:

Conference on Lasers and Electro-Optics, 2003. CLEO '03.

Link to article, DOI:

10.1109/CLEO.2003.1298075

Publication date:

2003

Document Version

Publisher's PDF, also known as Version of record

Link back to DTU Orbit

Citation (APA):

Jensen, J. B., Pedersen, L. H., Carlsen, A., Hoiby, P. E., Nielsen, L. B., Bjarklev, A. O., \& Hansen, T. B. (2003). Photonic crystal fiber based evanescent-wave sensor for detection of biomolecules in aqueous solutions. In

Conference on Lasers and Electro-Optics, 2003. CLEO '03. IEEE. https://doi.org/10.1109/CLEO.2003.1298075

\section{General rights}

Copyright and moral rights for the publications made accessible in the public portal are retained by the authors and/or other copyright owners and it is a condition of accessing publications that users recognise and abide by the legal requirements associated with these rights.

- Users may download and print one copy of any publication from the public portal for the purpose of private study or research.

- You may not further distribute the material or use it for any profit-making activity or commercial gain

- You may freely distribute the URL identifying the publication in the public portal 


\title{
Photonic crystal fiber based evanescent-wave sensor for detection of biomolecules in aqueous solutions
}

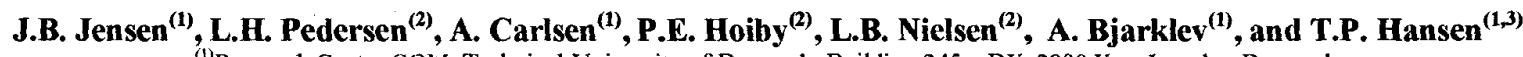 \\ ${ }^{(1)}$ Research Center COM, Technical University of Denmark, Building 345v, DK-2800 Kgs. Lyngby, Denmark \\ ${ }^{(2)}$ Biotechnological Institute, Kogle Alle 2, DK-2970 Horsholm, Denmark

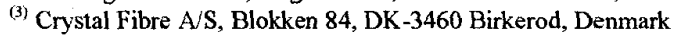 \\ J.B. Jensene-mail: jbi@com.dtu.dk
}

\begin{abstract}
We demonstrate evanescent-wave sensing of Cy5-DNA-molecules in an aqueous solution using a photonic crystal fiber. Less than $0.8 \mu \mathrm{L}$ sample volume placed in the holes of the fiber is sufficient for reliable detection.

(C)2002 Optical Society of America

OCIS codes: $(000.0000)$ General
\end{abstract}

\section{Introduction}

Since the advent of silica based Photonic Crystal Fibers (PCF) several unique properties have been demonstrated and utilized. Endlessly single-mode guidance [1], and a high degree of freedom in the design of the dispersion properties of the fiber [2], are some of the properties, which make PCF's an interesting alternative to standard optical fibers. Recently an interest in using the holey structure of the PCF for sensing purposes has arisen [3]. The penetration of the optical field into the air-filled holes can be quite significant [4], and the fraction of the light propagating in the holes is even higher when the holes are filled with a liquid. The overlap between the optical field and the liquid is still lower than in conventional spectroscopy, but the long interaction length obtained when using a PCF based device compensates this. The small volumes required to fill tens of centimeters of fiber thus makes a $\mathrm{PCF}$-device an interesting new solution when ultra small sample volumes are available. We have used a PCF with a large air-filling factor (Fig. 1) for evanescent-wave sensing of an aqueous solution of Cy5-DNA molecules.

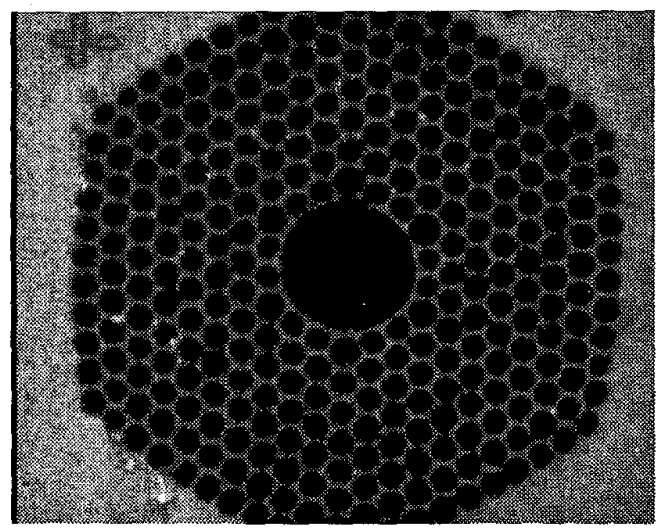

Fig. 1 Cross section of the photonic crystal fiber used for the evanescent wave sensor. The diameter of the microstructured part of the fiber is $79 \mu \mathrm{m}$.

\section{Experimental}

Using capillary forces $17 \mathrm{~cm}$ of the fiber was filled with a $25 \mu \mathrm{M}$ solution of Cy5-DNA. The molecule is highly fluorescent and the filling of the fiber was monitored by epiflourescence microscopy (Fig 2). Light propagating in the liquid filled fiber is primarily guided in the silica structures throughout the microstnuctured cladding. The smallness of these structures forces a large percentage of the light to penetrate into the liquid, thus providing a 


\section{CTuP5}

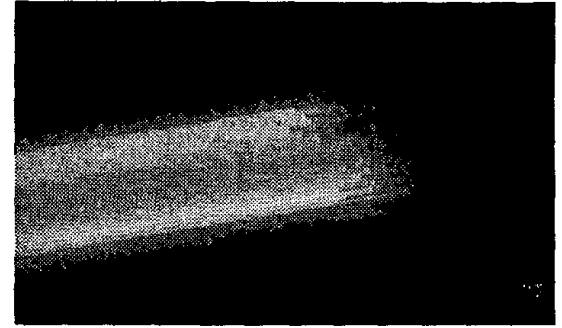

Fig. 2. A picture of the fluorescence from the PCF filled with a $25 \mu \mathrm{M}$ Cy5-DNA solution.

strong interaction between the light and the molecules in the liquid. This makes the hollow-core PCF used in this study superior to those microstructured fibers, where a large majority of the guided light is propagating in a solid silica core. Cy5-DNA absorbs strongly around $650 \mathrm{~nm}$, thereby making detection possible by monitoring the transmission spectrum of white light propagating through the fiber. White light was launched into the fiber using a microscope objective. The transmitted power was measured with an Ando optical spectrum analyzer (AQ-6315A) at a resolution of $1 \mathrm{~nm}$.

\section{Results and discussion}

Transmission spectra were measured for a PCF filled with an aqueous solution of Cy 5 and a reference fiber filled with pure water. From the transmission spectra the absorption spectnum was derived. A comparison between the absorption spectra of the Cy5 solution and the reference is seen in Fig 3.

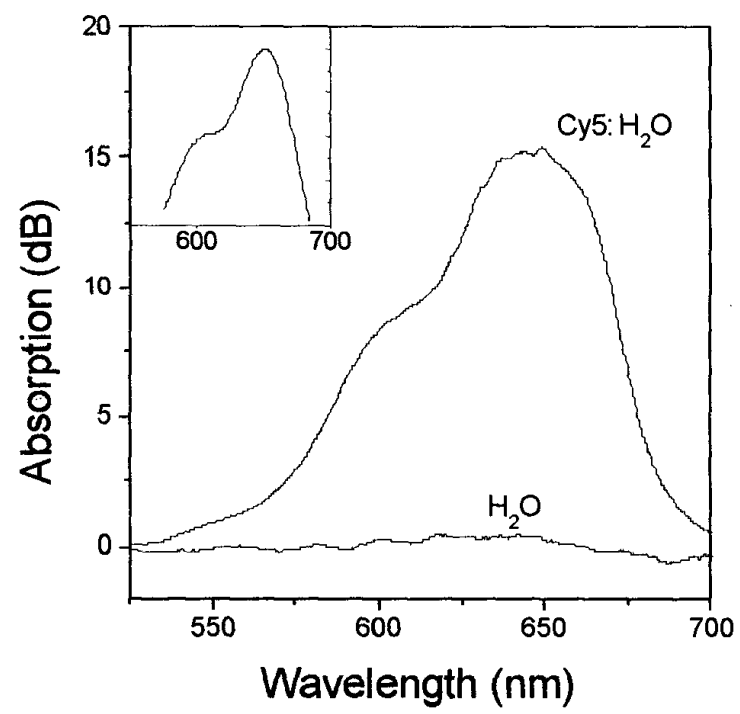

Fig. 3. The measured absorption spectrum of the Cy5 solution compared with the reference fiber. The insert shows a measurement of the Cy5 absorption spectrum using a conventional spectrometer.

Given the size of the PCF it is evident that the volume of the liquid is below $0.8 \mu \mathrm{L}$, which is a very small volume in sensor applications. Still the absorption spectrum clearly shows that the device is capable of detecting the presence of $\mathrm{Cy} 5$ in the solution.

\section{Conclusion}

We have demonstrated the use of a photonic crystal fiber as an evanescent-wave sensor for the detection of biomolecules in an aqueous solution. Based on our measurements we conclude that the fiber used in our work is highly suitable for sensing the presence of a given molecule in a very small sample volume. 


\section{CTuP5}

\section{References}

1.T.A. Birks, J.C. Knight, and P.St.J.Russell, "Endlessly single-mode photonic crystal fiber," Opt. Lett. 22, 961 -963 (1997)

2.A. Ferrando, E. Slivestre, P. Andres, J.J. Miret, and M.V. Andres, "Designing the properties of dispersion -flattened photonic crystal fibers," Opt. Express $9(13),(2001)$.

3.Y.L. Hoo, W. Jin, H.L. Ho, D.N. Wang, and R.S. Windeler, "Evanescent-wave gas sensing using microstructure fiber," Opt. Eng. 41 (1), 8-9 (2002).

4.T.M. Monro, D.J. Richardson, and P.J. Bennett, "Developing holey fibres for evanescent filed devices," Electron. Lett. 35 (14), (1999) 